\title{
Effective Usage of Cell Phone in Delivering Livestock Services by Field Veterinarians in Puducherry
}

\author{
J. Tamizhkumaran ${ }^{1}$, Natchimuthu. $\mathrm{K}^{2}$ \\ ${ }^{1}$ Ph.D Scholar, Department of Veterinary and A.H. Extension Madras Veterinary College, Chennai - 600007 \\ (This is Paper from part of M.VSc thesis) \\ ${ }^{2}$ Associate Professor, Department of Veterinary and A.H. Extension, Rajiv Gandhi Institute of Veterinary Education and Research, \\ Puducherry -605009
}

\begin{abstract}
A study was conducted in the purposively selected Puducherry region. All the veterinarians who were using cell phones to deliver the livestock services were selected as the respondents. Data relevant to the objectives of study were collected from 16 field veterinarians through Questionnaire method. The results showed that majority of the veterinarians were middle aged, male with B.V.Sc degree. The cell phones were widely used by the field veterinarians to contact various stakeholders in livestock sector. Almost all veterinarians were contacted through cell phone by the livestock owners to avail the livestock services at their door steps. Most of the field veterinarians received less than 100 calls in a week with respect to livestock services and spent an amount of Rs. 201 to 500 for cell phones every month. Most of the veterinarians used key persons to pass the information to livestock owners. Most of the veterinarians said that they did not face any problem in delivering the services through cell phones. Other problems faced by the veterinarians were untimely calls, unwanted calls, and wrong calls from ignorant livestock owners. This study clearly brought out that the cell phone; a powerful ICT tool is being used effectively by the veterinarians in delivering livestock services to the livestock owners at the time of need at their doorsteps.
\end{abstract}

Keywords: veterinarians, ICT, Livestock Services, Cell phone usage

\section{Introduction}

\section{"Telecommunication is the key tool for socio-economic transformation"}

Livestock sector plays an important role in socio-economic development of rural households in India and the contribution to the total GDP was 4.07 per cent during 200809 (DAHD, 2010). About 68 per cent of population lives in more than 6.38 lakh villages of India (GOI, 2011). About 70 per cent of rural households are dependent on livestock for income (Chawla et al., 2005). Improvement in livestock production is, therefore, an important pathway for increasing the income of marginal and small farmers and landless labourers (Venkatasubramanian and Rao, 2011).

Information plays an important role in reducing the uncertainty (Rogers, 2003). Knowledge dissemination on scientific livestock management is one of the most important services to improve the livelihoods of livestock dependent families (Garforth, 2003). Veterinarians are a critical part and major stakeholder of any livestock service delivery system. They are the link with the livestock owners and hence have insights into the ground level reality (Punjabi et al., 2005).

The access to affordable telecom services is the most important development that has happened in the rural areas of our country after the green revolution (Singh, 2011). Cell phones are increasingly becoming popular; they have become a symbol of the use of new ICTs in the developing world (Sarin and Jain, 2009). The mobile phones have a great affordability than any other ICTs (Mucemi et al.,
2009). In India out of 885 million telephone subscribers 851 million people use cell phones as on June 2011 (TRAI, 2011). Puducherry is not an exception to this situation. Telecommunication is the fastest growing industry particularly in India (next to China). Eighty percent of cell phone users are in developing countries, however research on mobile telephony in developing countries has been relatively limited (Donner, 2008).

In Puducherry also, cell phones are widely used by veterinarians and the stakeholders of livestock development. However, no systematic study has been carried out to find out the nature and extend of use of cell phones by the field veterinarians. Hence, a study was conducted with the main objective to find the extent of use of cell phones by the field veterinarians in delivering the services to the livestock owners in Puducherry region.

\section{Materials and Methods}

The study was conducted in the purposively selected Pondicherry region of the UT of Puducherry. The study was confined to the livestock services which includes the service receiver (cell phone owned livestock owner) and the service provider (the field veterinarian). All the five rural communes and two municipalities of Puducherry region were included in this study. All the field veterinarians (20) under the Puducherry region were considered, Out of which only 16 field veterinarians were selected based on the criteria of veterinarian-farmer contacts through cell phone usage. The respondents were selected purposively since the sample size was less in the study area. Thus a total of 16 field veterinarians who had a well established contact with 


\section{International Journal of Science and Research (IJSR) \\ ISSN (Online): 2319-7064}

Index Copernicus Value (2013): 6.14 | Impact Factor (2014): 5.611

livestock owners through cell phones were included in this study.

\section{Modus Operandi}

Each veterinarian has a unique way of approaching the livestock owners for delivering livestock services. Majority of the veterinarians take a note on calls received by them daily and plan and proceed to their cases. They also note the address of the livestock owners who call them for first time. Usually when a veterinarian receives a call from the livestock owner he asks for the symptoms and detailed history from the livestock owner so that he goes well prepared to attend the case with appropriate medicines and equipments. Most of them go for house calls after $11 \mathrm{am}$ after disposing the cases at the dispensary. Only in case of emergency the veterinarians goes for house calls during office hours. Some veterinarians take a note of the name of the livestock owners and enter it into the diary and give him a tentative time of visit to attend the case. If the call is from a new livestock owner, he makes a note of his/her cell phone number too. Usually the veterinarian goes out with a attender to treat the cases. The Veterinarian usually priortise the cases and prepare a route plan to attend emergency cases first and other cases later. The preference is usually given to the emergency cases like dystocia, fracture, retention of placenta and bloat in which the life of the animal is at risk. Some veterinarians are delivering livestock services only to the office hours from morning 8.30 am to evening $5 \mathrm{pm}$ whereas some other veterinarians are providing services even in midnight.

The veterinarians usually prefer to visit a livestock owner's house. As the number of calls a veterinarian receives is always more than the number of calls he can attend. His choice then depends upon

1) Seriousness of the case

2) Socio-economic status of the client

3) Distance to be travelled

4) Ability and willingness of the client to pay the fee and

5) Previous experience with the client

Whenever veterinarians do not have time to attend the cases they depute their sub ordinates personally mainly to attend cases of minor importance, like artificial insemination, follow up cases and wound treatments. Some veterinarians follow a particular route for seeing the cases, whereas some draw/fix a route based on calls they received and some follow a standard route and attend all house calls. Only few lady veterinarians are not attending to the outdoor cases. It is also observed that veterinarian's interest in attending the case of the livestock owner is directly linked with the amount of money expected in lieu of service delivery. Few veterinarians give special preference to AI cases because they get money with minimum effort and less risk. One more feature is that when a veterinarian visits a village to attend a case they also visit the livestock owners' farm with whom they have good relationship to enquire about the health of other animals. The lady veterinarians usually attend cases only during office hours. The prioritisation is based on the relationship already established, influence/ position of the livestock owners, the amount the livestock owner pay, distance from dispensary etc. Some veterinarians insist the livestock owners to bring their cattle to the dispensary when the distance between their house and dispensary is less.

\section{Results and Discussion}

\section{Profile of the veterinarian respondents}

Majority were middle aged with B.VSc degree. Out of the 16 veterinarian respondents, 10 were male and the rest were female. The ratio of male to female veterinarian in Puducherry was low compared to other states where only less number of lady veterinarians was in field service.

\section{Experience in using a cell phone by the veterinarian respondents}

All the 16 field veterinarians owned a cell phone. Almost all the respondents $(81 \%)$ had an experience of using cell phone ranging from 6 and 12 years. There were 6 per cent of the respondents who had more than 12 years of experience. The finding clearly indicated that majority of the veterinarians had an experience of more than 6 years (Table $1)$.

Table 1: Experience in using cell phone by the veterinarian respondents

\begin{tabular}{|c|l|c|c|}
\hline Sl.No & \multicolumn{1}{|c|}{ Experience } & Frequency & Percentage \\
\hline 1 & Upto 5 years & 2 & 12.50 \\
\hline 2 & 6-12 years & 13 & 81.25 \\
\hline 3 & Above 12 years & 1 & 06.25 \\
\hline & Total & 16 & 100.00 \\
\hline
\end{tabular}

Mean: 8.3

Range: 3-16

The average experience of the field veterinarians in using the cell phone was more than 8 years, whereas the livestock owners had maximum of 5 years experience in using cell phones.

\section{Purpose of receiving calls from livestock owners through cell phone}

The purpose for which the veterinarians were contacted by the livestock owners are given in the table.2. The results revealed that all the veterinarians were contacted to obtain information regarding livestock rearing which showed that veterinarians were the credible information source as reported by Ramkumar et al (2003). About 15 veterinarians were contacted for treatment purpose and 11 veterinarians were contacted for AI services.

Table 2: Purpose of receiving calls from livestock owners through cell phone, $\mathrm{N}=16^{*}$

\begin{tabular}{|c|l|c|c|}
\hline Sl.No & \multicolumn{1}{|c|}{ Purpose } & Frequency & Percentage \\
\hline 1 & Information & 16 & 100.00 \\
\hline 2 & Treatment & 15 & 93.75 \\
\hline 3 & Artificial insemination & 11 & 68.75 \\
\hline
\end{tabular}

*multiple responses

Cases for which the veterinarians were contacted through cell phone

The veterinarians were contacted by the livestock owners for various purposes. However, considerable share of calls were used to invite the veterinarians mainly for treatment of

\section{Volume 4 Issue 12, December 2015}




\section{International Journal of Science and Research (IJSR) \\ ISSN (Online): 2319-7064}

Index Copernicus Value (2013): 6.14 | Impact Factor (2014): 5.611

emergency cases which included dystokia (8), bloat (8), and uterine prolapse (2). It was also used for the other emergency cases like snake bite, fracture, poisoning, accident and rabies bite. Some of the livestock owners had contacted veterinarian through cell phone even for clinical cases such as acidosis, retention of placenta, mastitis, indigestion, pyrexia, ephemeral fever, milk fever, lameness and pneumonia. In general the cell phones were made use of by the livestock owners to invite the veterinarians to attend emergency cases.

\section{Number of livestock related calls received by the veterinarian in a week}

Most of the field veterinarians (81\%) received less than 100 calls in a week with respect to livestock services, whereas 2 veterinarians received more than 500 calls in week (Table 3 ). The number of calls received by the veterinarians varied from 10 to 700 calls in a week. This wide variation might be due to the ability and interest of the field veterinarian, sex of the veterinarian in addition to the place of posting of the veterinarian.

Table 3: Number of livestock related calls received by the veterinarian in a week

\begin{tabular}{|c|l|c|c|}
\hline Sl.No & No. of calls received & Frequency & Percentage \\
\hline 1 & Up to 100 calls & 13 & 81.25 \\
\hline 2 & 101 to 500 calls & 1 & 06.25 \\
\hline 3 & Above 500 calls & 2 & 12.50 \\
\hline & Total & 16 & 100.00 \\
\hline
\end{tabular}
Mean: 116.25

The purpose for which the calls received by field veterinarians in a week time includes all the livestock delivery services viz. clinical, breeding and information. The two veterinarians who received more number of calls were due to their extended time of service delivery, interest in attending private cases and good rapport they established with many livestock owners.

Amount spent on recharging of cell phone by the veterinarian respondent in a month

Majority of the respondents (44\%) used an amount of Rs. 201 to 500 for recharging their cell phones every month (Table 4). About 37 per cent of the respondent used up to Rs. 200 and the remaining 18 per cent used an amount of above Rs. 500.

Table 4: Amount spent on recharging of cell phone by the veterinarian respondent in a month

\begin{tabular}{|c|l|c|c|}
\hline Sl.No & Amount spent on recharging & Frequency & Percentage \\
\hline 1 & Upto Rs. 200 & 6 & 37.50 \\
\hline 2 & Rs.201- 500 & 7 & 43.75 \\
\hline 3 & Above Rs.500 & 3 & 18.75 \\
\hline & Total & 16 & 100.00 \\
\hline
\end{tabular}

Mean: 275, Range: 100- 4000

Most of the veterinarians used their cell phones for general and personal purpose. They use their cell phones to contact farmers very rarely. Most of the veterinarians used the office landline to communicate to livestock owners. Hence, it was difficult to relate the amount spent on cell phone and quantum of livestock delivery services undertaken by them.
Different sources which contacts the veterinarian through cell phone

Veterinarians were receiving cell phone calls from all stakeholders of livestock development. All the veterinarians were contacted by the livestock owners for various livestock service which include clinical, breeding and information services. About 15 veterinarians said they were contacted by fellow veterinarians of the department for enquiry or sharing their experience in a new case which they treated (Table 5). About 13 veterinarians said they received calls from their sub ordinates for consultation/guidance. Five veterinarians told that they received calls from medical representative who visits them frequently and also from the DCS secretary.

Table 5: Different sources which contacts the veterinarian through cell phone, $\mathrm{N}=16^{*}$

\begin{tabular}{|c|l|c|c|}
\hline Sl.No & \multicolumn{1}{|c|}{ Different sources } & Frequency & Percentage \\
\hline 1 & Livestock owner & 16 & 100.00 \\
\hline 2 & Veterinarian from other dispensary & 15 & 93.75 \\
\hline 3 & Para veterinarian & 13 & 81.25 \\
\hline 4 & Medical representative & 5 & 31.25 \\
\hline 5 & DCS Secretary & 4 & 25.00 \\
\hline
\end{tabular}

Type of information for which the veterinarian is contacted by the livestock owners

The veterinarians were asked to list out the type of information for which the livestock owners contacted them through cell phone. The responses revealed that a majority veterinarians (14) received calls for obtaining the information on how to give a first aid for emergency cases before their arrival. Eleven veterinarians received calls related to arrival and availability of the feed in the department through government schemes, 9 received calls related to management of animals for better production, 8 received calls related to information loan for purchasing animals 4 received calls related to insurance claim (Table 6).

Table 6: Type of information for which the veterinarian is contacted by the livestock owners, $\mathrm{N}=16$

\begin{tabular}{|c|l|c|c|}
\hline Sl.No & Information Obtained & Frequency & Percentage \\
\hline 1 & First Aid information & 14 & 87.50 \\
\hline 2 & Availability of feed & 11 & 68.75 \\
\hline 3 & Management doubts & 9 & 56.25 \\
\hline 4 & Information on loan & 8 & 50.00 \\
\hline 5 & Insurance claim & 4 & 25.00 \\
\hline
\end{tabular}

*multiple responses

\section{Experience of veterinarian as a resource person using}

The experience of veterinarians on delivering information through phone-in programme, radio, television, lectures, discussions etc was assessed (Table 7). The data revealed that most of the veterinarians $(63 \%)$ did not participate in any of the above said programmes. The main reason expressed by them was that they neither had time nor were interested in giving programmes. Only six veterinarians participated as resource persons in AIR and Doordhasan programmes related to livestock rearing. Some of these veterinarians had also attended live programmes both in television and phone-in programmes. Incidentally all these six veterinarians were working in minor veterinary dispensaries. 


\section{International Journal of Science and Research (IJSR) ISSN (Online): 2319-7064}

Index Copernicus Value (2013): 6.14 | Impact Factor (2014): 5.611

Table 7: Experience of the veterinarian as a resource person

\begin{tabular}{|c|l|c|c|}
\hline Sl.No & \multicolumn{1}{|c|}{ Category } & Frequency & Percentage \\
\hline 1 & Resource person & 6 & 37.50 \\
\hline 2 & Not a resource person & 10 & 62.50 \\
\hline & Total & 16 & 100.00 \\
\hline
\end{tabular}

\begin{abstract}
Means used by veterinarians to contact livestock owners The veterinarians had their own way of contacting or conveying the messages to the livestock owners. The different methods used by them are categorized and presented in Table (8). Most of the veterinarians (69\%) used key persons like WSHG leaders, DCS milk tester and local healers for contacting or passing the information to livestock owners. Equally they used their department staff viz., assistant veterinarian and attenders to contact the livestock owners, about 38 per cent of the veterinarians used their cell phone directly to contact the livestock owners and 31 per cent of the veterinarians used the help of DCS secretary to communicate with the livestock owners.
\end{abstract}

Table 8: Means used by the veterinarians to contact the livestock owners

\begin{tabular}{|c|l|c|c|}
\hline S.No & \multicolumn{1}{|c|}{ Means } & Frequency* & Percentage \\
\hline 1 & Key persons & 11 & 68.75 \\
\hline 2 & Department staff & 11 & 68.75 \\
\hline 3 & Cell phone & 6 & 37.50 \\
\hline 4 & Others & 6 & 37.50 \\
\hline 5 & DCS secretary & 5 & 31.25 \\
\hline
\end{tabular}

*multiple responses

\begin{abstract}
Problems in use of cell phone in delivery of livestock services as perceived by veterinarians

The veterinarians expressed that they faced some problems while delivering livestock services as listed in table 9. Most of the veterinarians said that they did not have any problem in delivering the services through cell phones which might be because of their interest in lucrative private practice. Some veterinarians said that the problem of getting untimely calls disturbed their day to day life. Some of the veterinarians even expressed that the unwanted calls frequently received by them made them tensed in their busy schedule. Some veterinarians even felt that it was difficult to do their personal work peacefully and some ignorant livestock owners who called them by mistake. Some veterinarians felt livestock owners calling them frequently before reaching their respective homes was a serious problem. There were instances where some of the field veterinarians were disturbed by the livestock owners in calling them by mistake instead of calling someone else out of their ignorance.
\end{abstract}

Table 9: Problems in use of cell phone in delivery of livestock services as perceived by veterinarians, $\mathrm{N}=16$

\begin{tabular}{|c|c|c|c|}
\hline Sl.No & Problems & Frequency & Percentage \\
\hline 1 & No problem & 6 & 37.50 \\
\hline 2 & Untimely calls & 4 & 25.00 \\
\hline 3 & Unwanted calls & 4 & 25.00 \\
\hline 4 & Disturbance during personal work & 2 & 12.50 \\
\hline 5 & $\begin{array}{c}\text { Livestock owner's ignorance in usage } \\
\text { of cell phone }\end{array}$ & 2 & 12.50 \\
\hline 6 & Repeated calling & 2 & 12.50 \\
\hline
\end{tabular}

**multiple responses

\section{Conclusions}

Cell phones are being used widely by the veterinarians in contacting the livestock owners to deliver the livestock services at their doorsteps. Livestock owners who need veterinarians' services at their door steps and have willingness to pay for the service were using cell phones to contact veterinarians which gave them an idea on what is the disease condition before attending the case. Cell phone helped many veterinarians to save their time and travel; it helped them communicating a message to the fellow veterinarian or para veterinarian and passing information to the livestock owners. Most of the veterinarians were contact through the cell phone for livestock services like clinical services and information services. The veterinarians feel that using cell phones gives them a preamble of the disease condition and help then in carrying the required medicine before reaching the actual spot to treat the animal.

\section{References}

[1] Chawla NK; Kurup, MPG and Shrama, VP (2005). State of Indian farmer, A millennium study, Section-12 , Animal Husbandry, Academic Foundation, New Delhi-110002.

[2] DAHD (2010). Department of Animal Husbandry, Dairying \& Fisheries, Ministry of Agriculture, Annual report (2009-10), Government of India, New Delhi.

[3] Donner J (2008). Micro entrepreneurs and mobiles: An exploration of the uses of mobile phones by small business owners in Rwanda. Information Technologies and International Development, 2(1): 1-21.

[4] Garforth C (2003). Management of knowledge and Information for improved Animal Health. In: Cattle health issues in the per-urban regions: potentials of information in coping with poverty, Proceedings of the workshop held on 20th and 21st March 2003 at Rajiv Gandhi College of Veterinary and Animal Sciences, Pondicherry.

[5] GOI (2011). Population Census - 2011. (http://censusindia.gov.in) accessed on 20.08.2011

[6] Mucemi G; Kristen W and Francois S (2009). ISTAfrica 2009 Conference Proceedings Paul Cunningham and Miriam Cunningham (Eds) IIMC International Information Management Corporation, 2009 www.ISTAfrica.org/Conference2009 accessed on 20.04.2011

[7] Punjabi. M, Kumar. P, Sreeramulu. P, Ahuja.V(2005) Livestock Service Delivery in Andhra Pradesh: Veterinarians' Perspective, Pro-Poor Livestock Policy Initiative - A Living from Livestock Research report RR Nr. 0507; August 2005 http://www.fao.org.pdf

[8] Rogers EM (2003). Diffusion of Innovations, $4^{\text {th }}$ ed. Free press, New York. pp no. 281.

[9] Sarin A and Jain R (2009). Effect of Mobile on socioeconomic life of urban poor, IIMA, India.

[10] Singh M (2011). Mobile Services Drove up TeleDensity on 20 January 2011, Special Correspondent, The Hindu.

[11] Tacchi J; Slater D and Hearn G (2003). Ethnographic Action Research. A User's Handbook. New Delhi, UNESCO. 


\section{International Journal of Science and Research (IJSR) \\ ISSN (Online): 2319-7064}

Index Copernicus Value (2013): 6.14 | Impact Factor (2014): 5.611

[12] TRAI (Telecom Regulatory Authority of India) (2011).Highlights of telecom subscription data as on 30 June 2011, Press report" TRAI, New Delhi. Accessed on 16.08.2011.

[13] Van den Ban AW (2002). Poverty alleviation among Farmers: the role of Knowledge. In: Wheelbarrows Full of Frogs: Social Learning in Rural Resource Management. The Netherlands: Koninklijke van Gorcum, pp.183-196

[14] Venkatasubramanian.V and Rao, S.V.N (2011). Livestock Extension Education, project directorate, North Eastern Region, ICAR, Pusa, New delhi. 